\title{
The Predictive Value of Day one Serum Bilirubin Extent for Subsequent Increase Substantial Hyperbilirubinemia in Well Full Term Neonate in Mukalla Maternity and Child Hospital, Hadhramout,Yemen
}

Saleh Awad Bahwal (MD,MSc) ${ }^{1}$, Mazin Ahmed Jawass(MD,MSc) ${ }^{2}$, Faiza Salmeen Naji $(\mathrm{CABP})^{3}$

${ }^{1}$ Department of Pediatrics, College of Medicine and Health Sciences, Hadhramout University, Yemen

${ }^{2}$ Department of Pediatrics, College of Medicine and Health Sciences, Hadhramout University, Yemen

${ }^{3}$ Department of Pediatrics, College of Medicine and Health Sciences, Hadhramout University, Yemen

Correspondence Address:

Saleh Awad Bahwal

Department of Pediatrics, College of Medicine and Health Sciences, Hadhramout University, Yemen email: dr.salehbahwal@yahoo.com

Received: 20 October 2020

Revised: 28 October 2020

Accepted: 24 November 2020

Published: 25 June 2021

Diyala Medical Journal 2021:20(2): 1-13

\section{Abstract}

Background: Significant neonatal hyperbilirubinemia is a common cause of readmission following initial sending home from hospitals in healthy mature neonates.

Objective: To determine the predictive ability of first $24^{\text {th }} \mathrm{hr}$ entire serum bilirubin (TSB) levels for later development of important hyperbilirubinemia in well mature neonates at Mukalla Maternity and Child Hospital (MMCH) in Mukalla city, Hadhramaut Governorate, Yemen.

Patients and Methods: A cross sectional study of 150 well mature newborns was tracked with everyday serum total bilirubin detections for five days of life at Mukalla Maternity \& Child Hospital between March 2019 and February 2020.

Results: It was observed that $10 \%, 10 \%, 13.3 \%$ and $66.7 \% \%$ of newborns were corresponding to high, high intermediate, low intermediate, and low risk zones respectively, while $7.3 \%$ of newborns had developed significant hyperbilirubinemia and needed phototherapy. The day one bilirubin value of $5 \mathrm{mg} / \mathrm{dl}$ had a sensitivity of $100 \%$ and specificity of $72 \%$, the positive predictive value of $22 \%$, and a negative predictive value of $100 \%$ in forecasting the risk of developing significant jaundice.

Conclusion: A total serum bilirubin measurement may be applied as a useful screening test for each neonate at the first week of life, to foresee those at risk for later development of 
significant neonatal hyperbilirubinemia and permit for a harmless discharge from the hospital.

Keywords: Jaundice; newborn; prediction; hyperbilirubinemia;Yemen

\section{Introduction}

Hyperbilirubinemia is common and usually a benign problem in newborns. Jaundice is detected during week one of life in nearly $60 \%$ of mature babies and $80 \%$ of immature babies [1]. Between $60 \%-80 \%$ of all term or late-term, healthy newborns exhibit idiopathic jaundice [2]. A significant hyperbilirubinemia occurs in about $5 \%-10 \%$ of healthy term neonates [3]. About $4 \%$ of mature babies who were readmitted to the NCU during week one of life, about $85 \%$ of them are readmitted for hyperbilirubinemia [4]. Prompt discharge of well mature babies has become a public rehearsal to avoid hospital infections, persuasion of early maternal-baby attachment and also lesser price [5]. Because of the increasing number of early discharged newborns, there is a corresponding danger of failing to diagnose severe hyperbilirubinemia .Timed TSB measurements (at discharge between 18 hours and 72 hours) can be used to predict the chances of developing severe hyperbilirubinemia [6].

Initial recognition of frightening bilirubin values allow commencement of phototherapy and avoids greater risk and a great rate of exchange transfusion or kernicterus also hour-specific bilirubin nomogram and TSB measurement can be used for predicting the subsequent need for phototherapy [7-9] .The American Academy of Pediatrics (AAP) clinical practice guideline endorses that all newborn infants should be assessed before discharge for the risk of developing significant neonatal hyperbilirubinemia [3].

The present study was carried out to determine the predictive ability of first $24^{\text {th }} \mathrm{hr}$ TSB levels for later development of substantial hyperbilirubinemia in well mature babies at Mukalla Maternity and Child Hospital.

\section{Patients and Methods}

A cross-sectional observational study of 150 well mature babies was tracked with everyday TSB detections for the initial five days of life at Mukalla Maternity \& Child Hospital in Mukalla city, Hadhramaut Governorate, Yemen, between March 2019 to February 2020.

Inclusion Criteria: Included babies were well mature neonates with body weight $\geq$ 2500 grams and maturity of $\geq 37 / 52$ and delivered vaginally or cesarean deliveries after ordinary pregnancy, with smooth delivery .

Exclusion criteria: Were prematurity, postterm, congenital anomalies, $\mathrm{Rh}$ or major ABO incompatibility, Infants presented with delayed meconium passage (> 24 hours), birth weight less than 2500. Low blood sugar, low body temperature, cephalhematoma, skin bruising, bleeding tendency of the newborn (vitamin $\mathrm{K}$ deficiency), birth asphyxia, renal system infection, and doubted neonatal infection were also omitted. 
Sample size: According to the available prevalence of significant hyperbilirubinaemia among neonates $11 \%$ [8]. The necessary sample size was 150. A systemic random sampling procedure was used, and we selected every $3^{\text {rd }}$ newborn baby delivered in the hospital after considering the inclusion and exclusion criteria.

All participants were exposed to the subsequent standard valuation for each baby by history, clinical assessment and laboratory tests. Interrogation included gender, mode of birth, thorough prenatal and natal history, gestational age, blood groups and $\mathrm{Rh}$, and family history of newborn jaundice. The clinical assessment comprised APGAR score, anthropometric dimensions, cutaneous color, the existence of bruises or cephalohematoma, valuation of GA (agreeing to New Ballard Score), [10], and reflexes (Moro and suckling). Serum total bilirubin determination was firstly made within 24hours of life and was repetitive daily for the next 4 days, 24 hours apart.

A percentile based neonates were divided in 4 risk zones using nomogram organized by Tiberi [11], the nomogram has 4 risk zones:

Neonates had their $24^{\text {th }} \mathrm{hr}$ TSB $<40^{\text {th }}$ percentile corresponding to the low risk zone. Neonates had their $24^{\text {th }}$ hr TSB level between $40^{\text {th }}-95^{\text {th }}$ percentile consistent to intermediate risk zone and sub divided into two groups:

Neonates $\mathrm{s}$ had their $24^{\text {th }}$ hr TSB level between $40^{\text {th }}-75^{\text {th }}$ percentile equivalent to low intermediate risk -zone.

Neonates had their $24^{\text {th }}$ hr TSB level between $76^{\text {th }}-95^{\text {th }}$ percentile equivalent to high intermediate risk zone.
Neonates had their $24^{\text {th }}$ hr TSB level $>95^{\text {th }}$ centile percentile corresponding to high risk zone.

Significant neonatal hyperbilirubinemia was classified according to AAP [3] after 72 hours of life into:

Group I: Babies developing significant hyperbilirubinemia (serum bilirubin $\geq 17 \mathrm{mg}$.) after the third day of life.

Group II: Babies developing non-significant hyperbilirubinemia (serum bilirubin $<17$ $\mathrm{mg})$ ) after the third day of life.

The research protocol and the questionnaires were conducted according to the principles of the Declaration of Helsinki. Verbal consents was also taken from the parents and caregivers of children involved in the study.

\section{Statistical analysis}

The data were veiled, tabularized, and statistically evaluated using SPSS package version 17. Data were abridged using range, mean, standard deviation, and percentages for quantitative variables or frequency and percentage for qualitative ones. Appraisal between groups was achieved using MannWhitney test for quantitative variables while appraisal for qualitative variables was made through Chi-square or Fisher's exact test. The specificity, sensitivity, positive predictive value (PPV) and negative predictive value (NPP) for the gained cut-offs were designed. $\mathrm{P}<0.05$ was considered important.

\section{Results}

150 babies were included in the study and TSB detection was firstly made within the initial 24hours of life (mean:19 \pm 3.6 hours) and were repetitive daily for the subsequent 4 days, acting each detection just 24 hours after 
the preceding measurement. Table (1) shows a significant association between male babies who had a TSB of $<5 \mathrm{mg} / \mathrm{dL}$ and of $\geq 5$ $\mathrm{mg} / \mathrm{dL}$ in the first 24 hours of life. There were also non-significant differences between the other clinical characteristics of the cases who had a TSB of $<5 \mathrm{mg} / \mathrm{dL}$ and of, $\geq 5 \mathrm{mg} / \mathrm{dL}$ in the first 24 hours of life.

Table (1): Demographic features of babies who had TSB level of $<5 \mathrm{mg} / \mathrm{dL}$ and $\geq 5 \mathrm{mg} / \mathrm{dL}$ in the day of life

\begin{tabular}{|c|c|c|c|}
\hline Variable & $\begin{array}{c}\text { Babies with TSB of } \\
<5 \mathrm{mg} / \mathrm{dL} \\
(n 5=100)\end{array}$ & $\begin{array}{c}\text { Babies with a TSB } \\
\text { of } \geq 5 \mathrm{mg} / \mathrm{dL} \\
(n=50)\end{array}$ & P-value \\
\hline $\begin{array}{l}\text { Sex } \\
\text { Boys } \\
\text { Girls }\end{array}$ & $\begin{array}{l}87(87 \%) \\
13(13 \%)\end{array}$ & $\begin{array}{l}35(70 \%) \\
15(30 \%)\end{array}$ & 0.01 \\
\hline $\begin{array}{l}\text { Gestational age (weeks) } \\
\text { mean } \pm \text { SD }\end{array}$ & $38.3 \pm 1.23$ & $38.6 \pm 1.25$ & 0.16 \\
\hline $\begin{array}{l}\text { Birth weight (grams) } \\
\text { mean } \pm \text { SD }\end{array}$ & $2873 \pm 392$ & $2793 \pm 192$ & 0.17 \\
\hline $\begin{array}{l}\text { Mode of delivery } \\
\text { Vaginal delivery } \\
\text { Cesarean delivery }\end{array}$ & $\begin{array}{l}60(60 \%) \\
40(40 \%)\end{array}$ & $\begin{array}{l}26(52 \%) \\
24(48 \%)\end{array}$ & 0.35 \\
\hline $\begin{array}{l}\text { Neonatal jaundice in } \\
\text { previous sibling } \\
\text { Yes } \\
\text { No }\end{array}$ & $\begin{array}{l}47(47 \%) \\
53(53 \%)\end{array}$ & $\begin{array}{l}20(40 \%) \\
30(60 \%)\end{array}$ & 0.41 \\
\hline $\begin{array}{l}\text { Oxytocin drug use } \\
\text { Yes } \\
\text { No }\end{array}$ & $\begin{array}{l}16(16 \%) \\
84(84 \%)\end{array}$ & $\begin{array}{l}7(14 \%) \\
43(86 \%)\end{array}$ & 0.74 \\
\hline $\begin{array}{l}\text { Type of feeding } \\
\text { Breast feeding } \\
\text { Bottle feeding } \\
\text { Mixed feeding }\end{array}$ & $\begin{array}{l}16(16 \%) \\
25(25 \%) \\
59(59 \%)\end{array}$ & $\begin{array}{l}7(14 \%) \\
10(20 \%) \\
33(66 \%)\end{array}$ & 0.74 \\
\hline
\end{tabular}

Table (2) shows a significant association between the clinical features of babies who did and who did not develop important hyperbilirubinemia $(\geq 17 \mathrm{mg} / \mathrm{dL})$ after 72 hours of life with respect to various factors such as male sex, neonatal jaundice in previous sibling and oxytocin drug use. None of the other maternal and neonatal characteristics were associated with the development of significant hyperbilirubinemia. 
Table (2): Demographic characteristics of babies who had and who had not developed substantial hyperbilirubinemia ( $\geq 17 \mathrm{mg} / \mathrm{dL})$ after third day of life

\begin{tabular}{|c|c|c|c|}
\hline Variable & $\begin{array}{c}\text { Babies with a TSBl of } \\
<17 \mathrm{mg} / \mathrm{dL} \\
(n=139)\end{array}$ & $\begin{array}{c}\text { Babies with a TSB } \\
\text { of } \geq 17 \mathrm{mg} / \mathrm{dL} \\
(n=11)\end{array}$ & P-value \\
\hline $\begin{array}{l}\text { Sex } \\
\text { Boys } \\
\text { Girls }\end{array}$ & $\begin{array}{l}114(82 \%) \\
25(18 \%)\end{array}$ & $\begin{array}{ll}6 & (54.5 \%) \\
5 & (45.5 \%)\end{array}$ & 0.03 \\
\hline $\begin{array}{l}\text { Gestational age (weeks) } \\
\text { mean } \pm \text { SD }\end{array}$ & $38.1 \pm 1.42$ & $38.7 \pm 2.12$ & 0.83 \\
\hline $\begin{array}{l}\text { Birth weight (grams) mean } \\
\pm \text { SD }\end{array}$ & $2883 \pm 190$ & $2793 \pm 221$ & 0.12 \\
\hline $\begin{array}{l}\text { Mode of delivery } \\
\text { Vaginal delivery } \\
\text { Cesarean section }\end{array}$ & $\begin{array}{l}79(56.8 \%) \\
60(43.2 \%) \\
\end{array}$ & $\begin{array}{l}7(63.6 \%) \\
4(36.4 \%) \\
\end{array}$ & 0.66 \\
\hline $\begin{array}{l}\text { Neonatal jaundice in } \\
\text { previous sibling } \\
\text { Yes } \\
\text { No }\end{array}$ & $\begin{array}{l}59(42.4 \%) \\
80(57.6 \%)\end{array}$ & $\begin{array}{l}9(81.8 \%) \\
2(18.2 \%)\end{array}$ & 0.02 \\
\hline $\begin{array}{l}\text { Oxytocin drug use } \\
\text { Yes } \\
\text { No }\end{array}$ & $\begin{array}{l}18(13 \%) \\
121(87 \%)\end{array}$ & $\begin{array}{l}5(45.5 \%) \\
6(54.5 \%)\end{array}$ & 0.008 \\
\hline $\begin{array}{l}\text { Type of feeding } \\
\text { Breast feeding } \\
\text { Bottle feeding } \\
\text { Mixed feeding }\end{array}$ & $\begin{array}{l}21(15.1 \%) \\
32(23 \%) \\
86(61.9 \%)\end{array}$ & $\begin{array}{l}2(18.2 \%) \\
3(27.3 \%) \\
6(54.5 \%)\end{array}$ & 0.78 \\
\hline
\end{tabular}

Table (3) illustrates 11 newborns (7.3\%) from a total of 150 neonates enrolled in the study and followed for 5 days, had developed substantial hyperbilirubinemia with serum total bilirubin levels of $\geq 17 \mathrm{mg} / \mathrm{dL}$ compared to $139(92.7 \%)$ who did not develop important hyperbilirubinemia with TSB of $<17 \mathrm{mg} / \mathrm{dL}$ after 72 hours of life $(\mathrm{p}<0.05)$.

Table (3): First five days' bilirubin levels of the babies who had and who had not developed substantial hyperbilirubinemia $(\geq 17 \mathrm{mg} / \mathrm{dL})$ after $3^{\text {rd }}$ day of age

\begin{tabular}{|c||c||c|c||}
\hline Days & $\begin{array}{c}\text { Insignificant } \\
\text { hyperbilirubinemias } \\
(\boldsymbol{n}=\mathbf{1 3 9})\end{array}$ & $\begin{array}{c}\text { Significant } \\
\text { hyperbilirubinemias } \\
(\boldsymbol{n}=\mathbf{1 1})\end{array}$ & P-value \\
\hline \hline Day 1 & $4.96 \pm 1.88$ & $6.34 \pm 1.79$ & $0.02^{* *}$ \\
& $(2.66-3.63)$ & $(5.25-8.13)$ & $0.01^{*}$ \\
\hline \hline Day 2 & $6.92 \pm 2.75$ & $9.10 \pm 1.11$ & $\mathrm{P}<0.001^{* * *}$ \\
& $(6.62-7.08)$ & $12.32-10.25)$ & $\mathrm{P}<0.001$ \\
\hline \hline Day 3 & $8.09 \pm 1.13$ & $(12.31-13.14)$ & $\mathrm{P}<0.001$ \\
& $(7.49-9.56) 8$ & $17.16 \pm 1.23$ & $(17.19-19.33)$ \\
\hline Day 4 & $9.37 \pm 1.72$ & $17.51 \pm 1.15$ & $(18.14-19.13)$ \\
& $(8.33-10.53)$ & & \\
\hline \hline Day 5 & $10.56 \pm 1.73$ & & \\
& $(9.85-10.87)$ & &
\end{tabular}


In the Table (4) the data was evaluated for later risk of evolving hyperbilirubinemia, an eleven $(7.3 \%)$ of babies developed important hyperbilirubinemia. Ten percent of babies $(15 / 150)$ had TSB levels in the high-risk zone $\left(>95^{\text {th }}\right.$ percentile) at the first 24 hours; of these, $(7 / 15$ or $46.7 \%)$ stayed in that zone, while $(4 / 15$ or $26.7 \%)$ moved downwards to intermediate high risk zone and (3/15 or $20 \%$ $\%)$ moved downwards to intermediate-low risk zone and (1/15 or $6.6 \%)$ moved downwards to low risk. Regarding the highintermediate risk zone, (3/15 or 20\%)of babies in the intermediate high risk zone moved upwards to high risk zone, while $(5 / 15$ or $33.3 \%)$ remained in same zone and (4/15 or $26.7 \%)$ moved down to low intermediate risk zone and (3/15 or $20 \%)$ moved down to low risk zone. On the other hand, low intermediate risk zone $(8 / 20$ or $40 \%)$ remained in the same zone, while $(9 / 20$ or $45 \%$ )moved down wards to low- risk zone and $(2 / 20$ or $10 \%)$ and $(1 / 20$ or $5 \%)$ moved upwards to intermediate high risk zone and high-risk zone respectively. While $66.7 \%$ of the newborns $(100 / 150)$ were in the low-risk zone $\left(<40^{\text {th }}\right.$ percentile) had no measurable risk for substantial hyperbilirubinemia.

Table (4): Subsequent risk categorization of study newborns after $72 \mathrm{hrs}$ of age

\begin{tabular}{|l||c||c||c||c||c||}
\hline \multicolumn{2}{|c||}{} & \multicolumn{2}{|c|}{ Subsequent risk categorization of study population after 72hrs of age } \\
\hline \hline Risk zone & $\begin{array}{c}\text { Total } \\
\text { number of } \\
\text { newborns } \\
(\mathbf{N = 1 5 0 )}\end{array}$ & Low risk & $\begin{array}{c}\text { Low } \\
\text { Intermediate } \\
\text { risk }\end{array}$ & $\begin{array}{c}\text { High Intermediate } \\
\text { risk }\end{array}$ & High risk \\
\hline \hline Low- risk zone & 100 & $100(100 \%)$ & $0(00)$ & $0(00)$ & $0(00)$ \\
\hline $\begin{array}{l}\text { Low-intermediate } \\
\text { risk zone }\end{array}$ & 20 & $9(45 \%)$ & $8(40 \%)$ & $2(10 \%)$ & $1(5 \%)$ \\
\hline $\begin{array}{l}\text { High-intermediate } \\
\text { risk zone }\end{array}$ & 15 & $3(20 \%)$ & $4(26.7 \%)$ & $5(33.3 \%)$ & $3(20 \%)$ \\
\hline \hline High risk zone & 15 & $1(6.6 \%)$ & $3(20 \%)$ & $4(26.7 \%)$ & $7(46.7 \%)$ \\
\hline
\end{tabular}

In the Table (5) the predictive capacity of the $40^{\text {th }}, 75^{\text {th }}$, and $95^{\text {th }}$ percentile tracks as risk demarcates. A day-one bilirubin level of $\geq 5 \mathrm{mg} / \mathrm{dl}$ had a sensitivity of $100 \%$ and specificity of $72 \%$, the positive predictive value of $22 \%$ and a negative predictive value of $100 \%$ in expecting the risk of developing significant neonatal jaundice. 
The Predictive Value of Day one Serum Bilirubin Extent for Subsequent Increase Substantial Hyperbilirubinemia in Well Full Term Neonate in Mukalla Maternity and Child Hospital, Hadhramout, yemen

Table (5): Sensitivity, specificity, and positive and negative predictive values of the first day of life in predicting the development of substantial hyperbilirubinemia

\begin{tabular}{|c|c|c|c|c|c|c|c|}
\hline \multicolumn{2}{|c|}{$\begin{array}{c}\text { Percentile track as risk } \\
\text { demarcator }\end{array}$} & \multicolumn{2}{|c|}{$\begin{array}{c}\text { Outcome: Subsequent } \\
\text { Significant } \\
\text { hyperbilirubinemia }\end{array}$} & \multicolumn{4}{|c|}{ Predictive characteristics } \\
\hline $\begin{array}{l}\text { Percentile } \\
\text { Track as risk } \\
\text { demarcator }\end{array}$ & $\begin{array}{l}\text { Number of } \\
\text { Newborns } \\
\text { (Total 150) }\end{array}$ & $\begin{array}{l}\text { Present } \\
\text { (Total 11) }\end{array}$ & $\begin{array}{c}\text { Absent } \\
\text { (Total 139) }\end{array}$ & PPV & NPV & Sensitivity & Specificity \\
\hline $\begin{array}{l}\text { Above } 95^{\text {th }} \\
\text { percentile }\end{array}$ & 15 & 7 & 8 & \multirow[t]{2}{*}{46} & \multirow[t]{2}{*}{97} & \multirow[t]{2}{*}{63} & \multirow[t]{2}{*}{94} \\
\hline $\begin{array}{l}\text { Below } 95^{\text {th }} \\
\text { percentile }\end{array}$ & 135 & 4 & 131 & & & & \\
\hline $\begin{array}{l}\text { Above } 75^{\text {th }} \\
\text { percentile }\end{array}$ & 30 & 10 & 20 & \multirow[t]{2}{*}{33} & \multirow[t]{2}{*}{99} & \multirow[t]{2}{*}{90} & \multirow[t]{2}{*}{85} \\
\hline $\begin{array}{l}\text { Below } 75^{\text {th }} \\
\text { percentile }\end{array}$ & 120 & 1 & 119 & & & & \\
\hline $\begin{array}{l}\text { Above } 40^{\text {th }} \\
\text { percentile }\end{array}$ & 50 & 11 & 39 & \multirow[t]{2}{*}{22} & \multirow[t]{2}{*}{100} & \multirow[t]{2}{*}{100} & \multirow[t]{2}{*}{72} \\
\hline $\begin{array}{l}\text { Below } 40^{\text {th }} \\
\text { percentile }\end{array}$ & 100 & 0 & 100 & & & & \\
\hline
\end{tabular}

Table (6) shows a total of 11(7.3) newborns who developed significant hyperbilirubinemia and needed phototherapy. $46.7 \%, 20 \%$ and $5 \%$ needed phototherapy in high risk zones, high intermediate risk and

Table (6): Determining the subsequent need of phototherapy treatment

\begin{tabular}{|l||c||c||}
\hline \multicolumn{1}{|c|}{ Risk zone } & Number of Newborns & $\begin{array}{c}\text { Number of newborns needed } \\
\text { phototherapy (\%) }\end{array}$ \\
\hline \hline Low risk zone & 100 & 0 \\
\hline \hline Low intermediate risk zone & 20 & $1(5 \%)$ \\
\hline \hline High intermediate risk zone & 15 & $3(20 \%)$ \\
\hline \hline High risk zone & 15 & $7(46.7 \%)$ \\
\hline \hline Total & 150 & $11(7.3 \%)$ \\
\hline
\end{tabular}

Figure (1) shows that $10 \%, 10 \%, 13.3 \%$ and $66.7 \% \%$ of newborns were corresponding to intermediate risk, and low-risk zones respectively. high risk, high intermediate risk, low 


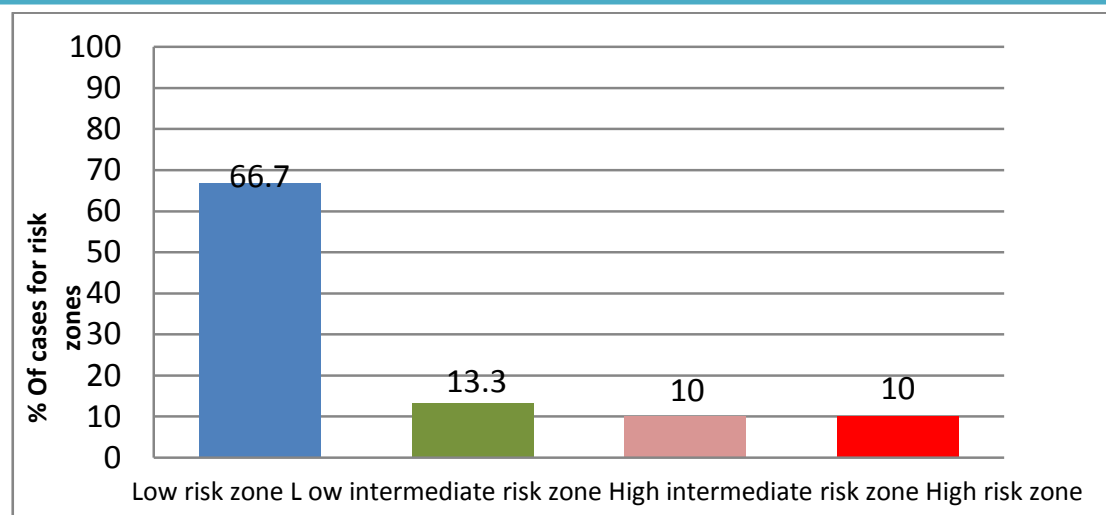

Figure (1): Risk stratification of studied babies founded on daily TSB level

Figure (2) shows risk zones of term babies grounded on their days-specific TSB levels. The high-risk zone is nominated by the $95^{\text {th }}$ percentile track. The intermediate-risk zone is segmented into upper- and lower-risk zones by the $75^{\text {th }}$ percentile path. The lowrisk zone has been demarcated by the $40^{\text {th }}$ percentile track.

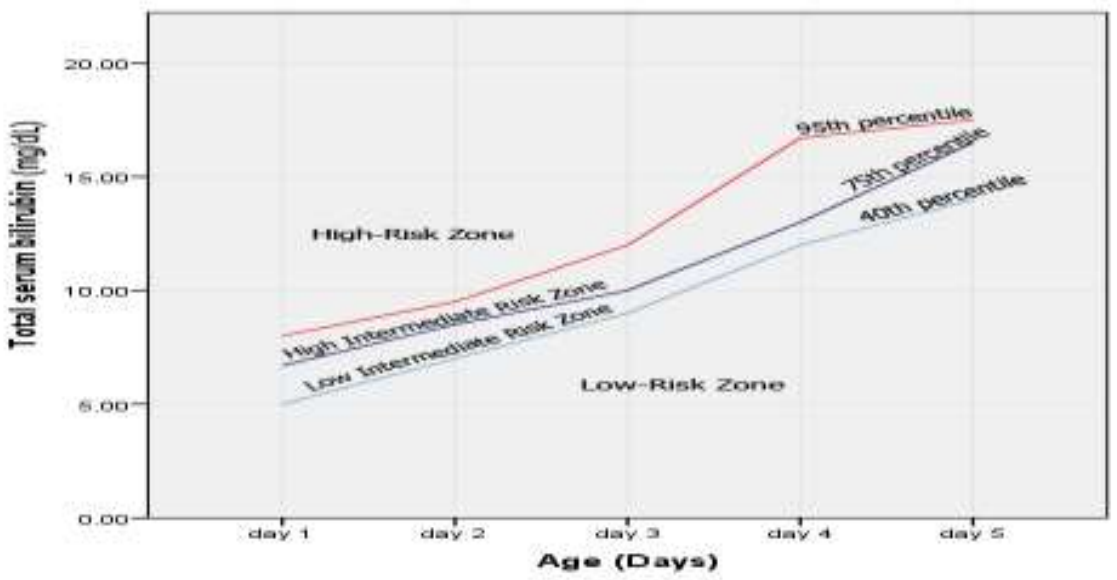

Figure (2): Risk zones of mature babies according to the percentile paths founded on their days-specific TSB levels

\section{Discussion}

The necessity for an early estimate of hyperbilirubinemia has become progressively significant for recognizing those newborns at risk of neonatal jaundice as the severe neurologic morbidities instigated by bilirubin toxicity [5].

In this article, we evaluated the ability of first day bilirubin level to be a means for showing the risk of succeeding neonatal hyperbilirubinemia. The frequency of substantial hyperbilirubinemia has been described to be $7.3 \%$. In 5 articles from 5 different states exploring the foretelling value of first-day TSB measurement on foreseeing the later development of substantial hyperbilirubinemia, the occurrence of substantial hyperbilirubinemia has been described to be between $4.4 \%-23.3 \%$ [11$15]$.

There was a substantial association between the male gender and the 
development of substantial hyperbilirubinemia $(\mathrm{P}<0.05)$ Table $(1)$ and Table (2).This is consistent with the other studies $[16,17]$.There is no clear mechanism explains that the healthy male can susceptible to the development of significant hyperbilirubinemia; such an effect need in the future analysis of a more comprehensive data set.

In this study, there was a substantial relationship between the newborns whose mother was given oxytocin for induction of labor and development of substantial neonatal jaundice $(\mathrm{p}<.05)$ Table $(2)$. This is consistent with the other studies $[15,18,19]$.This could be clarified by the mechanism of jaundice with oxytocin induction of labor. Oxytocin persuades hyponatremia and hypo-osmolality in the mom by virtue of its anti-diuretic and saluretic properties. These biochemical variations are intensified by the distillation of electrolyte-free dextrose fluid used as a van for giving oxytocin. Transplacentally spread hypo-osmolality in the fetal blood, leads to boosted osmotic brittleness of the red blood cells. The distended and hyper brittle erythrocytes are effortlessly stuck by the spleen ending in net higher bilirubin creation [20].

A substantial relationship was noted between the existence of siblings with hyperbilirubinemia and the development of substantial hyperbilirubinemia $\quad(\mathrm{P}<0.05)$ Table (2).This is in agreement with the earlier studies [21-23].Positive family history can serve as a marker for shared genetic susceptibility [24].Gene polymorphisms in the hepatic uridine diphosphate glucuronosyltransferase isoenzyme 1A1 (UGT1A1 ) and the solute transporter organic anion carrier 1B1(SLCO1B1), alone or in the mixture, impact the occurrence of neonatal jaundice [1].

Regarding high intermediate risk zone, $(3 / 15$ or $20 \%)$ of babies in the high intermediate risk zone moved upwards to high risk zone, while $(5 / 15$ or $33.3 \%)$ stayed in a similar area and (4/15 or 26.7\%) progressed down to low intermediate risk zone and $(3 / 15$ or $20 \%)$ moved down to low risk zone. On the other hand, lowintermediate risk zone $(8 / 20$ or $40 \%)$ remained in same zone, while $(9 / 20$ or $45 \%$ moved down wards to low risk zone and $(2 / 20$ or $10 \%)$ and $(1 / 20$ or $5 \%)$ moved upwards to high intermediate risk zone and high risk zone respectively. $66.7 \%$ of the babies (100/150) was in the low-risk zone $\left(<40^{\text {th }}\right.$ percentile) and there was no computable risk for substantial jaundice. The proportion of newborns in risk zones was nearly to that described in texts by Tiberi et al [11] and Pathak et al [25].

Kireeti and Srividya [26] found that 94.8\%) did not develop substantial hyperbilirubinemia and 5.2\% had substantial hyperbilirubinemia. $33.33 \%$ (15/45) of babies in the intermediate risk zone remained in low risk zone. $17.77 \%(8 / 45)$ neonates in the intermediate risk zone went up to lowintermediate risk zone. 26.66\% (12/45) babies in the intermediate risk zone went up to high-intermediate risk zone. $22.22 \%$ (10/45) newborns in the intermediate risk zone went into high risk zone. All the 3 newborns belonging to high risk zone remained in high risk zone.

In this study, the TSB of $5 \mathrm{mg} / \mathrm{dL}$ on day one of life had a sensitivity of $100 \%$ and 
specificity of $72 \%$, the positive predictive value of $22 \%$ and negative predictive value of $100 \%$ in predicting the risk of developing significant jaundice. A $100 \%$ negative predictive value in this study proposes that detection of TSB in the first day of life can help recognize those babies who are not likely to need further assessment and interference. Compared to previous studies on the predictive values of various TSB levels in the first day of life in foreseeing the development of substantial hyperbilirubinemia [11-15], our series shows some similarities and differences. These variances may be related to different inclusion standards, as they comprised all live births, while we encompassed a definite group of live birth. In adding to tribal and environmental disparities in diverse inhabitants, different design of the study and laboratory variability in the measurement of bilirubin. Sriram and Paramahamsa [27] found that 1st 24hours bilirubin level of $>4.9 \mathrm{mg} / \mathrm{dl} / \mathrm{dL}$ had a sensitivity of $88.89 \%$, specificity of $71.68 \%$, the negative predictive value of $97.6 \%$. $\%$ and positive predictive value of $32.9 \%$ in predicting significant neonatal hyperbilirubinemia. Mittana and Arimilli [28], found that with the $1^{\text {st }} 24$ hours bilirubin level of $5.45 \mathrm{mg} / \mathrm{dl}$ disclosed that it has a sensitivity of $87.9 \%$., specificity of $82 \%$, the negative predictive value of $97.16 \% \%$, and positive predictive value of $49.15 \%$, in predicting neonatal hyperbilirubinemia. When the facts were evaluated for the consequent risk of evolving hyperbilirubinemia, a total of 11(7.3) neonates established substantial hyperbilirubinemia and needed phototherapy. $5 \%$ of $(1 / 20), 20(3 / 15 \%)$ and $46.7(7 / 15 \%)$ needed phototherapy in low intermediate risk, high intermediate risk and high risk zones respectively and no one of the babies in the low-risk zone given phototherapy. Our study line with that of Kishore Kumar et al.,[29] , who found that 4\%, 26\%, and $77 \%$ needed phototherapy in lowintermediate risk, high- intermediate risk and high risk zones respectively and none of the babies in the low-risk zone given phototherapy. In the Bhutani series $2 \%, 13 \%, 40$ needed phototherapy in low intermediate risk, high intermediate risk and high-risk zones respectively and no one of the babies in the low-risk zone given phototherapy [11].

At the mean serum TSB level of $\geq 5 \mathrm{mg} / \mathrm{dL}$ in the first day of life, the sensitivity $(100 \%)$ and negative predictive value $(100 \%)$ were very high in foreseeing the ensuing necessity of phototherapy.This result was in agreement with other studies [11, 30].

No baby in the study group requisite an exchange transfusion or settled a TSB level $>25 \mathrm{mg} / \mathrm{dL}$. No one had acute signs of bilirubin encephalopathy. All have had normal development at about 1 year of age during follow up.

Limitations of the study were, only full term healthy neonates were taken for the study and a large number trial that include both mature and premature newborns and large multicentric studies need to be done on Yemen babies before the conclusions can be generalized and to establish more sensitive and more predictive rules.

\section{Conclusions}

A TSB detection and the use of precarious bilirubin value of $5 \mathrm{mg} / \mathrm{dl}$ in the first day of life will forecast early all well term babies 
who will have substantial hyperbilirubinemia and will define all those infants who will necessitate a phototherapy later during the first few days of life.

\section{Recommendations}

So the treating clinicians will take care of the problem to make decision about the mode of therapy and whether to discharge the baby home safely.

\section{Source of funding: Nil}

Ethical clearance: This study was granted ethical approval from the Ethical Committee of the Collage of Medicine at Diyala medical University

Conflict of interest: The authors of this article have no conflict of interest of any type.

\section{References}

[1]Shaughnessy EE, Goya NK. Jaundice and hyperbilirubinemia in the newborn. In Nelson Textbook of Pediatrics $\left(21^{\text {th }}\right.$ ed). KliegmanRM, Geme JW, Blum NJ, Shah SS, Tasker RC, Wilson KM, Behrman RE (eds), W. B Saunders company, 2019; chapter 123.3, pp 4097-4112.

[2]Ullah S, Rahman K, Hedayati M. Hyperbilirubinemia in Neonates: Types, Causes, Clinical Examinations, Preventive Measures and Treatments: A Narrative Review Article. Iran. J. Public Health 2016;45(5):558-68.

[3]American Academy of Pediatrics Subcommittee hyperbilirubinaemia. Management of hyperbilirubinaemia in the newborn infant 35 or more week of gestation. Pediatrics 2004; 114(1): 297-316. [4]Kiely M, Drum MA, Kessel W. Early discharge, risks, benefits and who decides. Clin perinatol 1998;25(3):539-53.
[5]Khairy MA, Abuelhamd WA, Elhawary IM, Mahmoud Nabayel AS. Early predictors of neonatal hyperbilirubinemia in full term newborn. Pediatr Neonatol 2019; 60(3):285290.

[6]Gregory ML, Martin CR, and Cloherty JP. Neonatal Hyperbilirubinemia. Manual of newborn care $\left(7^{\text {th }}\right.$ ed $)$.ClohertyJP, Eichenwald EC, Hansen AR, Martin CR, Stark AR. .Wolter Kluwer: Philadelphia; 2008. chapter 26, p. 304-339.

[7]Knudsen A. Prediction and non-invasive assessment of neonatal jaundice in the term healthy newborn infant. ActaPaediatr1996;85(4):393-7.

[8]Keren R, V Bhutani, $\mathrm{X}$ Luan, S Nihtianova, A Cnaan, J Schwartz. Identifying newborns at risk of significant hyperbilirubinaemia: a comparison of two recommended approaches. Arch Dis Child. 2005 Apr; 90(4): 415-421.

[9]Boskabadi H, Sezavar M, Zakerihamidi M. Evaluation of neonatal jaundice based on the severity of hyperbilirubinemia. J Clin Neonatol 2020;9:46-51.

[10]Ballard, JL; Khoury, JC; Wedig, K; Wang, L; Eilers-Walsman, BL; Lipp, R. "New Ballard Score, expanded to include extremely premature infants.". The Journal of Pediatrics 1991; 119 (3): 417-23.

[11]Tiberi E, Latella C, Parenti D, Romagnoli C. Predittività di un algoritmo previsionale dell'iperbilirubinemia neonatale nel neonato a termine [Predictive ability of a predischarge hour-specific serum bilirubin for hyperbilirubinemia in full term infants]. Minerva Pediatr. 2007 Jun;59(3):183-9. [12]Mazahy MM, Elkhalegy HA, Emran TM and Abdelhady RA. Value of First-day Serum Bilirubin Measurement in Predicting 
the Development of Neonatal Hyperbilirubinemia. Trends in Medical Research 2014; 9(2): 98-106.

[13]Unsur MT, Unsur E, Inan N, Ipek IO, Bozaykut A. The Predictive Value of Firstday Bilirubin Levels in the Early Discharge of Newborns. Iranian Journal of Neonatology 2015; 6(3).

[14]Khan KA, Alam J, Nahar N, Dey SK, Mannan MA, Shahidullah M. Predicting Neonatal Hyperbilirubinemia Using First Day Serum Bilirubin Level in Late Preterm and Term Healthy Newborn. Mymensingh Med J 2017;26(4):854-862.

[15]Allam JB, Kumar S, Kurmi R, Ara R, Kumar AM. First day serum bilirubin level, as predictor of significant hyperbilirubinemia in neonates. Arch Med Health Sci 2018;6(2):218-22.

[16]Najib KS, Saki F, Hemmati F, Inaloo S. Incidence, risk factors and causes of severe neonatal hyperbilirubinemia in the South of iran (fars province).Iran Red Crescent Med J 2013;15(3):260-3.

[17]Lake EA, Abera GB, Azeze GA, Gebeyew NA, and Demissie BW. Magnitude of Neonatal Jaundice and Its Associated Factor in Neonatal Intensive Care Units of Mekelle City Public Hospitals, Northern Ethiopia. International Journal of Pediatrics .2019, ID 1054943.

[18]Kishore MS, P. Rao T, DinendraramK. Prediction of significant hyperbilirubinemia using 24 hour serum bilirubin Int $\mathrm{J}$ ContempPediatr 2016;3(1):173-178.

[19]Rajpurohit N , Suresh Kumar S , Sharma D, ChoudharyM and Purohit S. To Assess Predictive Value of Cord Blood Bilirubin and Albumin for Significant Neonatal Hyperbilirubinemia: A Prospective Study from India. JPediatr Neonatal Care 2015; 2(1): 00060.

[20] Oral E, Gezer A, Cagdas A, Pakkal N. Oxytocin infusion in labor: the effect different indications and the use of different diluents on neonatal bilirubin levels. Arch GynecolObstet 2003; 267(3): 117-120.

[21]Bulbul A, Cayonu N, Sanli ME, Uslu S. Evaluation of risk factors for development of severe hyperbilirubinemia in term and near term infants. Pak J Med Sci 2014;30(5):1113-1118.

[22]Abdel-Aziz T, Azab N, Odah M, I.M. Eldeen IM. Factors and Assays Identifying Babies at Risk to Develop Significant Hyperbilirubinemia. International Journal of Innovative Research in Science, Engineering and Technology 2014; 3(2): 9804- 9809.

[23]Tomerak RH, Helal NF, Shaker OG, Yousef MA. Association between the Specific UGT1A1 Promoter Sequence Variant (c-3279T $>\mathrm{G})$ and Unconjugated Neonatal Hyperbilirubinemia. J Trop Pediatr 2016; 62(6):457-463.

[24]Dolan SM, Moore C. Linking family history in obstetricand pediatric care: assessing risk for genetic disease and birth defects. Pediatrics 2007;120(2):S66-70.

[25]Pathak U, Chawla D, Kaur S, Jain S.Bilirubin nomogram for prediction of significant hyperbilirubinemia in north Indian neonates. Indian Pediatr 2013;50(4):383-9. [26]Kireeti AS, Srividya L. The role of first day serum bilirubin estimation in predicting significant hyperbilirubinaemia in healthy term newborns. Int $\mathrm{J}$ Res Dev Health 2014;2(2):58-69.

[27]Sriram G, Paramahamsa RR. Predictive value of serum bilirubin level for identifying term neonates at risk for subsequent 
hyperbilirubinemia. Int $\mathrm{J}$ Contemp Pediatr 2019; 6(5):1914-21.

[28]Mittana N, Arimilli V. Role of cord blood serum bilirubin and 24 hour serum bilirubin in predicting the neonatal hyperbilirubinaemiaon the 5thday of life. J. Evid. Based Med. Healthc 2020; 7(19), 947952.

[29]Kishore Kumar R, Chandrasekaran M, Mahindre A, Harish B. Predischarge Risk Factors for Predicting Significant Hyperbilirubinemia in Term and Near-term Infants. J Ped Moth Care 2016; 2(1): 107. [30]Alpay F, Sarici SU, Tosuncuk HD, Serdar MA, Inanc N, Gokcay E. The value of First Day Bilirubin Measurement in Predicting the Development of Significant Hyperbilirubinemia in Healthy Term New borns. Pediatrics.2000; 106(2): E16. 